\title{
Effect of temperature on the development, growth, survival and settlement of green mussel Perna viridis (Linnaeus, 1758)
}

\author{
Manoj Nair $\mathbf{R}^{1}$ \& K K Appukuttan ${ }^{2}$ \\ ${ }^{1}$ Aquaculture Research Scientist, U.S.D.A. Land Grant, Cooperative Research \& Extension, College of the Marshall Islands, \\ Majuro, Republic of the Marshall Islands \\ ${ }^{2}$ Head, Molluscan Fisheries Division, Central Marine Fisheries Research Institute (C.M.F.R.I.), Cochin, Kerala, India
}

Correspondence: Manoj Nair R, Aquaculture Research Scientist, U.S.D.A. Land Grant, Cooperative Research \& Extension, College of the Marshall Islands, PO Box 1258, Majuro, MH 96960, Republic of the Marshall Islands. E-mail: manojnair999@yahoo.com

\begin{abstract}
The effect of temperature on the development, growth, survival and settlement of Perna viridis was studied under controlled conditions to provide information needed for the development of commercial hatchery technology for green mussel $P$. viridis. Total mortality of the larvae occurred after $24 \mathrm{~h}$ at temperatures of $33{ }^{\circ} \mathrm{C}$ and $35^{\circ} \mathrm{C}$. At $24^{\circ} \mathrm{C}$, larvae took longer to settle than at temperatures of $27{ }^{\circ} \mathrm{C}, 29^{\circ} \mathrm{C}$ and $31{ }^{\circ} \mathrm{C}$. For optimum larval development $(8-13 \mathrm{~h})$, growth $\left(17.2 \pm 0.84 \mu \mathrm{may}^{-1}\right)$ and survival $(55.2 \pm$ $0.84 \%$ ), a hatchery rearing temperature of $31{ }^{\circ} \mathrm{C}$ is required. For settlement no significant difference was seen between the percentage settlement at $29{ }^{\circ} \mathrm{C}(49.3 \pm 3.34 \%)$ and $31{ }^{\circ} \mathrm{C}(45.8 \pm 1.76 \%)$. However, the process of settlement began and ended earlier at $29^{\circ} \mathrm{C}$ (from 15 to 18 days) than at $31^{\circ} \mathrm{C}$ (from 18 to 20 days). Thus for larval settlement a temperature of $29^{\circ} \mathrm{C}$ is recommended.
\end{abstract}

Keywords: Perna viridis, green mussel, settlement, temperature, survival

\section{Introduction}

Mussel culture in India using Perna viridis and Perna indica was developed by the Central Marine Fisheries Research Institute (CMFRI) in the mid- and late 1970s. Two decades later the first commercial culture of mussels (green mussel $P$. viridis) was started in late 1995 at Anthakaranazhi (Alleppey district) in Kerala by local fishermen on long lines in the sea with the technical support of CMFRI. Commercial mussel culture activity along the southwest coast of India expanded greatly since 1997 in different parts of the country (Appukuttan, Mohamed, Kripa, Ashokan, Anil, Geetha, Velayudhan, Laxmilatha, Koya, Radhakrishnan, Joseph, Alloycious, Surendranathan, Nagaraja, Jenni \& Naik 2001) and cultured mussel production is expected to be about 800 tonnes in 2002 and is projected to be 12000 tonnes by the year 2007-2008 (K. K. Appukuttan, pers. comm.).

At present seed requirements for mussel farming in India are met mainly from the wild. Widespread mussel spat settlement occurs in the intertidal and subtidal areas during the post-monsoon period. However, substantial quantities of these spat perish due to various adverse ecological conditions (Appukuttan et al. 2001). Hence insufficient quantities of seed could become a major bottleneck in the expansion of mussel culture in India. Recent studies indicate that the seed availability for farming is limited and the seed requirement cannot be met only from the wild for commercial-scale mussel production by culture. Thus, the development of commercially viable hatchery technology becomes a priority for long-term sustainable and successful mussel farming in India.

In many invertebrates, the degree of tolerance to various physicochemical factors like temperature, salinity or $\mathrm{pH}$ varies during ontogeny. A detailed assessment of the importance of each of these factors based on field studies alone is difficult because of a lack of control and simultaneous changes in more than one variable. Detailed information on 
tolerances to changes in various factors can be obtained from laboratory experiments conducted under controlled environmental conditions.

Several investigations have been carried out to elucidate the importance of salinity and temperature in bivalve species, especially for mussel larval settling under natural conditions (Hancock 1973; Bayne 1976; Lutz \& Kennish 1992) and under controlled conditions (Loosanoff \& Davis 1963; Bayne 1965, 1976, 1983; Widdows 1991; Lutz \& Kennish 1992). Generally, two types of experiments are carried out: e.g. monofactorial experiments where the effect of one parameter is studied at a time (Loosanoff \& Davis 1963; Bayne 1965; AQUACOP 1979; Sprung 1984a-d; Sreenivasan, Rao, Poovannan \& Thangavelu 1988b; Sreenivasan, Rao \& Poovannan 1989; Satuito, Natoyama, Yamazaki \& Fusetani 1994; Tan \& Wong 1996), or multivariate experiments studying the effects of more than one factor at a time (Bayne 1976, 1983; Robert, His \& Dinet 1988; His, Robert \& Dinet 1989; Hurley \& Walker 1997; Doroudi, Southgate \& Mayer 1999). Several authors have investigated the effects of temperature independently and in multivariate experiments with salinity and feeding level on the growth and survival of mussel larvae in the laboratory (Bayne 1965, 1976, 1983; Hrs-Brenko \& Calabresse 1969; Hrs-Brenko 1973; Lough \& Gonar 1973; Widdows 1973; Lough 1974, 1975; Siddall 1979a, b; Beaumont \& Budd 1982; Falmagne 1983, 1984; Trevelyan \& Chang 1983; Sprung 1984a; Eyster \& Pechenik 1987; Pechenik, Eyster, Widdows \& Bayne 1990).

While taking up large-scale hatchery production of mussel seed, research and development efforts must be directed towards defining optimal conditions for growth, survival and reducing the duration of larval life. The purpose of the present study was to find out the optimum temperature for the development, growth, survival and settlement of green mussel $P$. viridis larvae reared under laboratory conditions. This work was undertaken with the larger objective of initiation of commercial hatchery techniques for the green mussel $P$. viridis in India and considering the fact that in tropical conditions no work has been done specifically on the temperature requirements of mussel larvae for growth, survival and settlement.

\section{Materials and methods}

\section{Larval rearing protocol}

All experiments on development and larval rearing were conducted at Tuticorin Research Centre $\left(8^{\circ} 45^{\prime} \mathrm{N}\right.$ latitude and $78^{\circ} 12^{\prime} \mathrm{E}$ longitude and is located in Tamil Nadu on the southeast coast of India) of the Central Marine Fisheries Research Institute (CMFRI) from August 1998 to October 1999. In total, four different runs of the same experiment were conducted with different broodstock. In these experiments healthy ripe $P$. viridis were collected and transported from Pondicherry $\left(11^{\circ} 46^{\prime}-12^{\circ} 30^{\prime} \mathrm{N}\right.$ latitude and $79^{\circ} 36^{\prime}-79^{\circ} 53^{\prime} \mathrm{E}$ longitude), $500 \mathrm{~km}$ from Tuticorin. The mussels spawned naturally without any inducement or stimulation.

The effect of temperature on mussel larval rearing was studied by growing the larvae in different temperatures, e.g. $24{ }^{\circ} \mathrm{C}, 27^{\circ} \mathrm{C}, 29^{\circ} \mathrm{C}$ (control, ambient water temperature), $31{ }^{\circ} \mathrm{C}, 33{ }^{\circ} \mathrm{C}$ and $35{ }^{\circ} \mathrm{C}$ (kept constant using a Jumo thermometer, relay and immersion heater system). Each of the experimental units for a temperature consisted of triplicate 5-L glass beakers with $4 \mathrm{~L}$ of fresh filtered sterilized seawater kept in 200-L fibreglass-reinforced plastic (FRP) tanks with $150 \mathrm{~L}$ of water. The Jumo thermometer, relay and immersion heater system was set for the appropriate temperature, with the silicon-cased immersion heater immersed in the FRP tanks. Even though no aeration was provided to the beakers, the FRP tank water was aerated to keep the temperature uniformly spread among the beakers during the trial. Beakers were covered with a black cloth to prevent contamination with dust and debris and also to prevent the growth of algae.

Larval rearing, sampling and estimation were done according to the protocols of Loosanoff \& Davis (1963), with some minor modifications. Briefly, after fertilization the eggs were collected by passing the contents through a $20-\mu \mathrm{m}$ sieve, thereby retaining the eggs but permitting the debris and damaged eggs to pass through. After estimation of the egg density, the desired number of eggs with a concentration of five eggs $\mathrm{mL}^{-1}$ was introduced into each culture beaker. All eggs per trial were taken from the same spawning stock, thus ensuring that all treatments matched closely in egg size. After $28 \mathrm{~h}$, the veliger larvae $(82.3 \pm 2.12 \mu \mathrm{m}$ (standard error of the mean in shell length)) were collected by passing the contents through a $70-\mu \mathrm{m}$ sieve, thereby retaining the veliger larvae and permitting the unfertilized eggs, fertilized eggs, embryos and trochophore larvae to pass through. At this point, the densities of veliger larvae in different experimental beakers were adjusted to two larvae $\mathrm{mL}^{-1}$. Seawater in each of the beakers was changed every $48 \mathrm{~h}$. At each time from each beaker, the larvae were collected on a mesh sieve 
$(60 \mu \mathrm{m})$, washed into a 1-L graduated cylinder and the volume made up to $1 \mathrm{~L}$. From this three $1 \mathrm{~mL}$ subsamples were removed to estimate the larval survival. In addition, the shell lengths of 60 larvae in each of the three beakers in the experimental unit were measured, noted and the larvae were released back to the respective beakers. This same procedure was carried out for each of the treatment temperature units. The experiment was terminated after complete settlement of the larvae, and the number of larvae in each beaker was counted. The growth, percentage survival and settlement were separately noted for each of the beakers in each of the treatment units. The same procedure was adopted for each of the four experimental runs.

There were no major fluctuations of water quality throughout the experimental period. Water quality parameters during the experiment were the following: salinity, $36 \pm 1$ ppt, pH $8.2 \pm 0.1$; dissolved oxygen, $5.2 \pm 0.3$ ppm; ammonia, $0.0014 \pm 0.001$ ppm; hydrogen sulphide: nil. Corresponding ambient air and water temperatures were $35 \pm 1{ }^{\circ} \mathrm{C}$ and $29{ }^{\circ} \mathrm{C}$ respectively.

\section{Feeding protocol}

The larvae were fed anexic unicultures of the microalgae Isochrysis galbana. The unicultures were cultured in 3-L glass haffkine flasks in autoclaved, 0.45$\mu \mathrm{m}$-filtered and UV-sterilized seawater using $\mathrm{f} / 2$ nutrient medium (Guillard 1983). The microalgae during the exponential growth phase $\left(1 \times 10^{6}{\left.\text { cells } \mathrm{mL}^{-1}\right)}^{-1}\right.$ were fed to the larvae. The microalgae cell concentration was determined by counting a subsample using a haemocytometer. The larvae were fed daily at 5000 cells larvae ${ }^{-1}$ from the veliger stage to the umbo stage, and at 8000 cells and 10000 cells larvae ${ }^{-1}$ from the umbo stage to the eyed stage and from the eyed stage to the pediveliger stage respectively. From the pediveliger stage through to the spat stage, the larvae were fed 16000 cells larvae ${ }^{-1}$. The required quantity of feed (depending on the larval survival in each of the experimental beakers) was taken from harvested fresh cultures and was acclimatized to the ambient water temperature conditions. It was then sieved through a $40-\mu \mathrm{m}$ sieve and poured uniformly into the larval rearing beaker just after the release of larvae.

\section{Statistical analyses}

Regression analysis using Microsoft EXCEL computer software (licensed to C.M.F.R.I. Cochin, Kerala, India) was performed to determine the relationships between shell lengths and age for each treatment unit (pooled for all the four experimental runs for each experimental unit). The results were presented in scatter diagrams with fitted lines. The significance of the relationships was measured using correlation coefficients $\left(r^{2}\right)$. The fitted lines for each temperature were also tested using pairwise $t$-tests with a significance level of $P<0.05$.

Statistical analyses of the actual growth rate data, percentage survival and percentage settlement data (pooled for all the four experimental runs for each experimental unit) were arcsine transformed (due to percentages) and analysed through a one-way analysis of variance (ANOVA) using Microsoft EXCEL computer software. In all cases, when the F-values of the treatments were significantly different, the best treatment was found out through pairwise (Student's $t$ test $P<0.05)$ comparison of treatment means. Pooled data for each of the treatment units for the percentage survival and percentage settlement were represented in bar graphs.

\section{Results}

There were no major differences in the results for the four different runs conducted for the temperature experiments. Hence the results of the four runs were pooled and presented for each of the temperature experiments. For $P$. viridis, 10, 8, 6 and $5 \mathrm{~h}$ were required for the fertilized eggs to reach the trochophore stage at $24{ }^{\circ} \mathrm{C}, 27^{\circ} \mathrm{C}, 29^{\circ} \mathrm{C}$ and $31^{\circ} \mathrm{C}$ respectively. Larvae required $30,22,14-18$ and $8-13 \mathrm{~h}$ to become veliger larvae at $24{ }^{\circ} \mathrm{C}, 27^{\circ} \mathrm{C}, 29^{\circ} \mathrm{C}$ and $31^{\circ} \mathrm{C}$ respectively. Development time and larval stage is given (Table 1 , Fig. 1). The growth of the larvae increased from a low temperature of $24{ }^{\circ} \mathrm{C}$ to a maximum growth at $31^{\circ} \mathrm{C}$. There was total larval mortality at $33{ }^{\circ} \mathrm{C}$ and $35^{\circ} \mathrm{C}$ after $24 \mathrm{~h}$. Settlement occurred fastest at $29^{\circ} \mathrm{C}$ (control temperature). Seven days were required to reach the umbo stage at $27^{\circ} \mathrm{C}$ and $31^{\circ} \mathrm{C}, 5$ days at $29^{\circ} \mathrm{C}$, and 8 days at $24{ }^{\circ} \mathrm{C}$. The eyed stage was reached on

Table 1 Development time from fertilized egg to veliger stage in $P$. viridis grown at different temperatures

\begin{tabular}{lllll}
\hline & \multicolumn{4}{l}{ Hours to attain the stage } \\
\cline { 2 - 5 } Stage & $\mathbf{2 4}^{\circ} \mathbf{C}$ & $\mathbf{2 7}^{\circ} \mathbf{C}$ & $\mathbf{2 9}^{\circ} \mathbf{C}$ & $\mathbf{3 1}^{\circ} \mathbf{C}$ \\
\hline $\begin{array}{l}\text { Trochophore } \\
\text { Veliger }\end{array}$ & 10 & 8 & 6 & 5 \\
& 30 & $22-26$ & $8-13$ & $13-18$ \\
\hline
\end{tabular}






Figure 1 Days to attain different larval stages in P. viridis grown in different temperatures.

days $9,11,17$ and 20 at $29{ }^{\circ} \mathrm{C}, 31^{\circ} \mathrm{C}, 27^{\circ} \mathrm{C}$ and $24{ }^{\circ} \mathrm{C}$ respectively. The pediveliger stage was observed on days $11,13,15$ and 27 at $29{ }^{\circ} \mathrm{C}, 31^{\circ} \mathrm{C}, 27^{\circ} \mathrm{C}$ and $24{ }^{\circ} \mathrm{C}$ respectively. The plantigrade stage was observed on days $13,15,17$ and 32 at $29^{\circ} \mathrm{C}, 31^{\circ} \mathrm{C}, 27^{\circ} \mathrm{C}$ and $24^{\circ} \mathrm{C}$ respectively. Settlement was observed at $29{ }^{\circ} \mathrm{C}$ from days $15-18$, whereas it took $18-20$ days at $31^{\circ} \mathrm{C}$. Settlement required $20-24$ days at $27^{\circ} \mathrm{C}$. Spat settlement was slowest at $24^{\circ} \mathrm{C}$, requiring 34-41 days.

The fitted regression lines and scatter plots between the shell length $(Y)$ and days $(X)$, with the corresponding fitted equation and the $r^{2}$ values for each temperature treatment, are given in Fig. 2. Overall larval growth increased with increased water temperatures. Growth rates were $6.01 \pm 0.19,10.44 \pm$ $0.895,12.08 \pm 0.56$ and $17.13 \pm 0.84 \mu \mathrm{m} \mathrm{day}^{-1}$ for $24{ }^{\circ} \mathrm{C}, 27^{\circ} \mathrm{C}, 29^{\circ} \mathrm{C}$ and $31{ }^{\circ} \mathrm{C}$ respectively (Fig. 3). The growth rates for days 1-10 showed a significant difference in larvae reared at $24{ }^{\circ} \mathrm{C}(3.85 \pm$ $\left.0.57 \mu \mathrm{m} \mathrm{day}^{-1}\right)$ and $27^{\circ} \mathrm{C} \quad\left(9.08 \pm 0.27 \mu \mathrm{m}_{\text {day }}{ }^{-1}\right)$. Growth was nearly four times faster at $29{ }^{\circ} \mathrm{C}$ $\left(13.26 \pm 0.62 \mu \mathrm{m} \mathrm{day}^{-1}\right)$ and at $31{ }^{\circ} \mathrm{C}(15.9 \pm 0.39 \mu \mathrm{m}$ day $^{-1}$ ) (Fig. 3). From days 10 to 21 growth rate doubled at $24{ }^{\circ} \mathrm{C}(6.19 \pm 0.22)$, whereas it was steady at $27{ }^{\circ} \mathrm{C}$

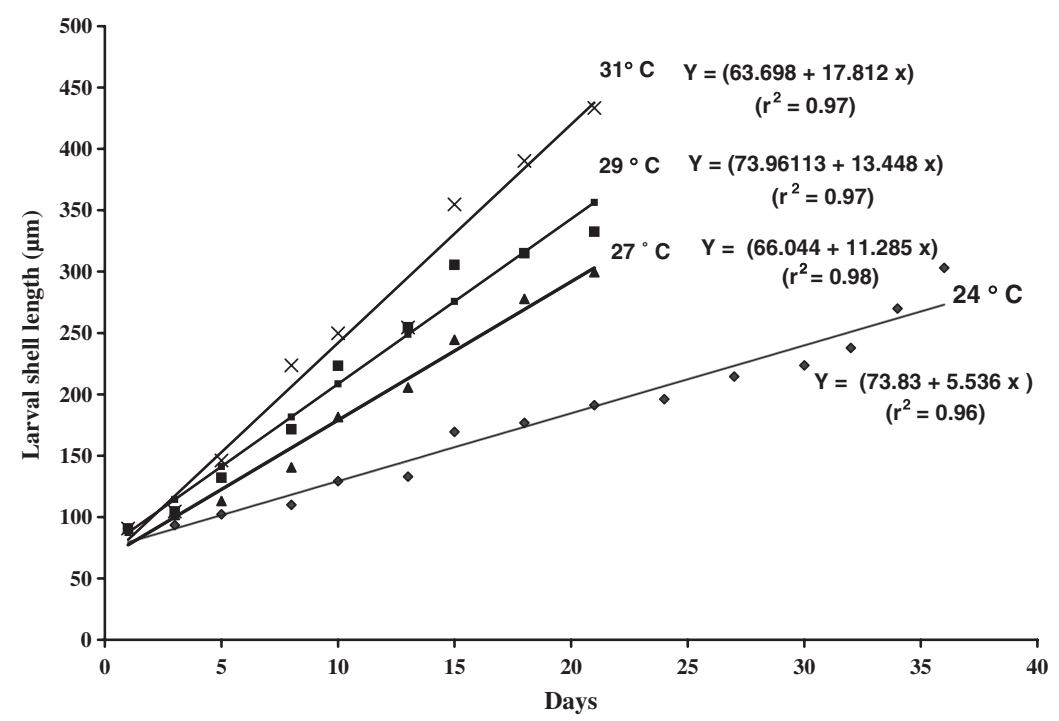

Figure 2 Regression lines of shell length for the effect of temperature on P. viridis larval growth. 


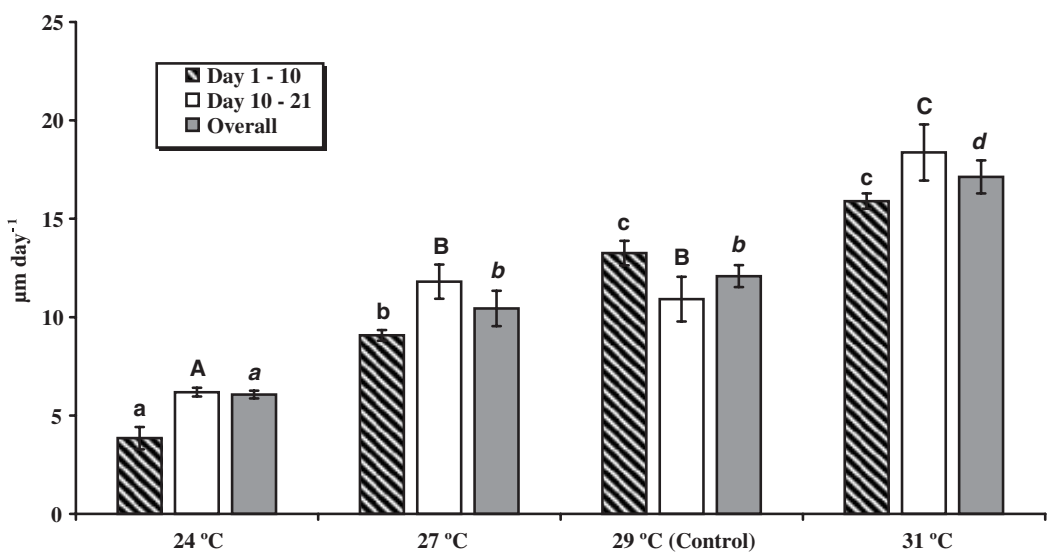

Figure 3 Growth rate of $P$. viridis larvae reared on different temperatures till settlement (mean \pm SE; $n=4)$. Means with the same subscripts are not significantly different $(P<0.05)$.



Figure 4 Effect of different temperatures on the percentage of larval survival and settlement in P. viridis (mean \pm SE; $n=4)$. Means with the same subscripts are not significantly different $(P<0.05)$.

$\left(11.08 \pm 0.87 \mu \mathrm{m} \mathrm{day}^{-1}\right)$ and slightly decreased at $29{ }^{\circ} \mathrm{C}\left(10.91 \pm 1.14 \mu \mathrm{m}_{\text {day }}{ }^{-1}\right)$. The greatest growth occurred at $31{ }^{\circ} \mathrm{C}\left(18.37 \pm 1.43 \mu \mathrm{m}_{\text {day }}{ }^{-1}\right)$ (Fig. 3). The growth of larvae at $24{ }^{\circ} \mathrm{C}$ was slower $(7.46 \pm 0.41 \mu \mathrm{m}$ day $^{-1}$ ) between days 21 and 36 (Fig. 3).

The percentage survival was $20.7 \pm 1.02 \%$, $31.5 \pm 2.26 \%, 43.7 \pm 1.11 \%$ and $55.2 \pm 2.19 \%$ at $24{ }^{\circ} \mathrm{C}$, $27{ }^{\circ} \mathrm{C}, 29{ }^{\circ} \mathrm{C}$ and $31{ }^{\circ} \mathrm{C}$ respectively (Fig. 4). The percentage settlement was $12 \pm 2.35 \%, 30.5 \pm 3.26 \%$, $49.3 \pm 3.34 \%$ and $45.8 \pm 1.76 \%$ at $24{ }^{\circ} \mathrm{C}, 27^{\circ} \mathrm{C}, 29{ }^{\circ} \mathrm{C}$ and $31{ }^{\circ} \mathrm{C}$ respectively (Fig. 4).

One-way ANOvA revealed a statistically significant difference among the temperature treatments. When the growth regression lines were tested $\left(r^{2}\right.$ values given in Fig. 2), there were significant differences
$(P<0.05)$ among the treatments, with a temperature of $31{ }^{\circ} \mathrm{C}$ yielding the highest growth. This was confirmed when the overall growth rate data were examined with a pairwise $t$-test. The overall growth rate at $31{ }^{\circ} \mathrm{C}$ differed significantly from the other temperatures, including the control. The control differed significantly from $24{ }^{\circ} \mathrm{C}$ but not with $27^{\circ} \mathrm{C}$. In the initial days $1-10$, a temperature of $31{ }^{\circ} \mathrm{C}$ was significantly different from all the other temperatures except for the control. However, for the rearing cycle (from days 10 to 21 ), the growth rate at $31{ }^{\circ} \mathrm{C}$ differed significantly from all the other temperatures including the control. The control differed significantly from $24{ }^{\circ} \mathrm{C}$ but not with $27^{\circ} \mathrm{C}$. Overall, the growth of larvae was highest at $31{ }^{\circ} \mathrm{C}$. 
Percentage survival was significantly different among the treatments $(P<0.05)$. Subsequent testing revealed that a temperature of $31{ }^{\circ} \mathrm{C}$ gave the highest larval survival. One-way ANOVA with the percentage settlement data showed that there was a significant difference $(P<0.05)$ in the percentage of larvae settling at the different test temperatures. Pairwise $t$-tests indicated that the settlement percentages did not differ significantly $(P<0.05)$ between $31{ }^{\circ} \mathrm{C}$ and $29^{\circ} \mathrm{C}$. However they differed significantly from $27{ }^{\circ} \mathrm{C}$ and $24{ }^{\circ} \mathrm{C}$. Settlement was best in the temperature range of $29-31{ }^{\circ} \mathrm{C}$.

\section{Discussion}

The results of the experimental larval rearing at six different temperatures indicated a direct relationship between temperature and larval growth, survival settlement and spat production. There was complete mortality after $24 \mathrm{~h}$ of the larvae reared at $33{ }^{\circ} \mathrm{C}$ and $35^{\circ} \mathrm{C}$, showing that high temperatures are not favourable for larval rearing of $P$. viridis. Bivalve larval growth rate increases with an increase in temperature to an optimum and then decreases (Bayne 1983; Widdows 1991). There are several reports of increase in the growth rates of larvae with increased temperature in mussels (Bayne 1965; Siddall 1979a, b; His et al. 1989; Trevelyan \& Chang 1983; Sprung 1984a). On the other hand, low temperature has also been reported to be preferable for the growth and survival of some bivalve larval species (Hrs-Brenko 1978; His et al. 1989; Lemos, Nascimento, De Araujo, Pereira, Bahia \& Smith 1994; Hurley \& Walker 1997), while Loosanoff (1954) found that temperature did not influence bivalve larval growth.

In the present study we observed that higher water temperatures gave better growth results than lower ones. This could be due to better feed assimilation at higher temperatures as reported by Loosanoff \& Davis (1963). The effect of temperature on the growth rate of bivalve larvae is primarily reflected on feeding, the metabolic processes and the rapid growth of the shell. The increased growth and survival of bivalve larvae at high temperature is primarily due to better assimilation of enzyme for feed digestion. According to Widdows (1991), the precise maximum growth rate varies throughout the geographic range of the species, with maximum growth rates occurring at high temperatures for larvae originating from lower latitudes. His et al. (1989) reported that discounting nutrition, temperature was clearly the dominant factor influencing the larval growth of bivalves.
The mortality of larvae at temperature $>33{ }^{\circ} \mathrm{C}$ is in agreement with the findings of most bivalve larval studies. There are no reports of larvae surviving at more than $32{ }^{\circ} \mathrm{C}$. Davis \& Calabrese (1964) found that although the larvae of $C$. gigas grew well and set at a high temperature, growth was reduced at $33^{\circ} \mathrm{C}$ and the larvae died at $35^{\circ} \mathrm{C}$. Bayne (1965) attributed mortality of Mytilus edulis larvae at $30{ }^{\circ} \mathrm{C}$ to the destruction of algal cells, leading to a bacterial buildup in the rearing system. Optimum temperature for bivalve larval rearing has been identified for the following temperate and tropical species (Table 2).

In $P$. viridis there has not been extensive research exclusively on the temperature of larval rearing except for Siddall (1979a, b), who found $26.4{ }^{\circ} \mathrm{C}$ as the best temperature for larval rearing carried out under high-latitude temperature conditions. Routine larval rearing has been conducted in this species at 25-28 ${ }^{\circ} \mathrm{C}$ (Rao, Kumari \& Qasim 1976; Sivalingam 1977; AQUACOP 1979, 1983; Sreenivasan et al. 1988a,b; Tan 1997) under tropical conditions.

The results from the present study indicated that mussel larvae are sensitive to low temperatures as indicated by poor growth, settlement and spat production. The inability of the larvae to grow at low temperatures could be due to their inability to digest ingested feed at those temperatures. Moreover, the results obtained in this study also contradict the results of Tan (1975) and Rao et al. (1976), who were able to settle the larvae at $23-25{ }^{\circ} \mathrm{C}$ and $25-27.4{ }^{\circ} \mathrm{C}$ in $8-12$ and 16-19 days respectively, whereas it took 34-45 days to settle the larvae in the present study at $24{ }^{\circ} \mathrm{C}$ in P. viridis. Generally, percentage settlement is positively correlated with an increase in temperature up to a point in most of the bivalves. Table 3 identifies the optimum temperature for mussel larval settlement for thetemperate and tropical species .

Table 2 Optimum temperatures for larval rearing reported for different bivalve species

\begin{tabular}{lll}
\hline Species & $\begin{array}{l}\text { Optimum } \\
\text { temperature }\left({ }^{\circ} \mathbf{C}\right)\end{array}$ & Reference \\
\hline Mya arenaria & $17.2-23.2$ & Stickney (1964) \\
Crassostrea gigas & $15-20$ & Helm \& Millican (1982) \\
Saccostrea ehinata & 29 & Coeroli et al. (1984) \\
Pinctada fucata & $28-32$ & Krishnan (1987) \\
Mytilus edulis & $15-20$ & Hrs-Brenko \& Calabrese \\
& & $(1969)$ \\
Perna perna & 27.7 & Siddall (1979a, b) \\
Perna viridis & 26.4 & \\
Perna viridis & 31 & Present study \\
\hline
\end{tabular}


Table 3 Optimum temperatures for larval settlement reported for different mussel species

\begin{tabular}{llll}
\hline Species & Temperature $\left({ }^{\circ} \mathbf{C}\right)$ & $\begin{array}{l}\text { Days for settlement/ } \\
\text { settlement stage }\end{array}$ & Reference \\
\hline Mytilus edulis & 16 & $16-20$ & Bayne (1965) \\
& 11 & $34-38$ & Hrs-Brenko (1973) \\
& 22.5 & 20 & \\
& 10 & 42 & Beaumont \& Budd (1982) \\
& 17 & 32 & Sprung (1984a) \\
& 18 & 20 & Eyster \& Pechenik (1987) \\
Mytilus galloprovincialis & 16 & 31 & Pechenik et al. (1990) \\
Mytilus californianus & 16 & $22-32$ & Hrs-Brenko (1978) \\
Perna perna & $20-26$ & 12 & Satuito et al. (1994) \\
Perna viridis & 18 & $26-32$ & Trevelyan \& Chang (1983) \\
Perna viridis & 20 & 22 & Siddall (1979a, b) \\
\hline
\end{tabular}

No work has been carried out specifically on the temperature requirements of mussel larvae for growth, survival and settlement under tropical conditions. We observed that although $31{ }^{\circ} \mathrm{C}$ was the best temperature for growth and survival, $29{ }^{\circ} \mathrm{C}$ was the best for settlement. Settlement was obtained on day 15 at this temperature and ended on day 18, while it took 18-21, 20-24 and 34-41 days for complete settlement at temperatures $31{ }^{\circ} \mathrm{C}, 27{ }^{\circ} \mathrm{C}$ and $24{ }^{\circ} \mathrm{C}$ respectively.

The results of this study are in agreement with those of other routine larval rearing experiments with the same or related mussel species. AQUACOP $(1979,1983)$ obtained spat settlement by 15-26 days at $24-28{ }^{\circ} \mathrm{C}$ for P. viridis, while Appukuttan, Nair \& Thomas (1984) and Appukuttan, Mathew \& Thomas (1988) obtained total spat settlement by 20-29 days for P. indica, whereas Rao et al. (1976) and Sreenivasan et al. (1988a, b) obtained total spat settlement by 15-19 and 16-20 days for $M$. viridis and $P$. viridis respectively. Tan (1997) obtained settlement by 18-30 days at $27-29{ }^{\circ} \mathrm{C}$ at varying salinities with optimum settlement at $24 \mathrm{ppt}$ by the 18 th day. Only the results of Tan (1975) contradict the majority of these results. He obtained the quickest larval settlement by $8-12$ days at a temperature of $23-25^{\circ} \mathrm{C}$ and at an optimum salinity of 28-30 ppt for $M$. viridis. For $P$. viridis it took 34-41 days in the present study to obtain complete settlement at $24^{\circ} \mathrm{C}$. Increased settlement at high temperature has been reported for other bivalves, mainly oyster and clams (Loosanoff, Miller \& Smith 1951; Loosanoff \& Davis 1963; Davis \& Calabrese 1964, 1969; Stickney 1964; Helm and Millican, 1982;
Henderson 1982; Coeroli, De Gaillande, Landret \& Coatanea 1984; Krishnan 1987), while no effect was observed by some others (Prytherch 1934; Bayne 1969).

According to Bayne (1983) and Strathmann(1987), at low temperatures larvae delay metamorphosis for longer periods than at high temperatures, and the duration of the free swimming larval period depends primarily on temperature. The percentage of larvae completing metamorphosis decreased progressively with each decrease in temperature (Davis \& Calabrese, 1964). They also mentioned that survival and growth of the larvae increased with increased temperature but within the limits of salinity and food concentration. Analysis of salinity and feed parameters of larval rearing of the related larval rearing experiments in P. viridis, $P$. indica, and $M$. viridis larvae reveal that salinity and food concentration (even though there was some variation in the feed concentration) were nearly the same. Variations in the results may be due to various reasons like speciesspecific variations, nutritional content of the diet or due to variations in the geographical ranges where the experiments were conducted.

\section{Acknowledgments}

The authors wish to thank the Director of CMFRI for providing the necessary facilities to conduct this research. M.N.R. wishes to thank Dr T.V. Sathianandan, for statistical advice and Dr P. Muthiah, Dr P.V. Sreenivasan, Dr P. Laxmilatha and Dr Balu for providing 
valuable suggestions. Finally, thanks are due to Central Institute of Fisheries Education (CIFE) and Indian Council of Agricultural Research (ICAR) for providing the necessary fellowship to M.N.R.

\section{References}

Appukuttan K.K., Mathew J. \& Thomas K.T. (1988) Larval rearing and spat production of brown mussel Perna indica (Kuriakose and Nair) at Vizhinjam, southwest coast of India. Bulletin of the Central Marine Fisheries Research Institute 42, 337-343.

Appukuttan K.K., Mohamed K.S., Kripa V., Ashokan P.K., Anil M.K., Geetha S., Velayudhan T.S., Laxmilatha P., Koya K.P.S., Radhakrishnan P., Joseph M., Alloycious P.S., Surendranathan V.G., Nagaraja D., Jenni S. \& Naik M.S. (2001) Survey of green mussel seed resources of Kerala and Karnataka. Marine Fish Information Service Technical \& Extension Series 168, 12-19.

Appukuttan K.K., Nair T.P. \& Thomas K.T. (1984) Larval rearing and spat settlement of brown mussel Perna indica in the laboratory. Marine Fish Information Service Technical $\mathcal{E}$ Extension Series 55, 12-13.

AQUACOP (1979) Larval rearing and spat production of green mussel Mytilus viridis Linnaeus in French Polynesia. Proceedings of the World Mariculture Society 10 , 641-647.

AQUACOP (1983) Mass production of spat of green mussel Mytilus viridis Linnaeus in French Polynesia. Proceedings of the Symposium on Coastal Aquaculture 2, 534-539.

Bayne B.L. (1965) Growth and the delay of metamorphosis of the larvae of Mytilus edulis (L.). Ophelia 2, 1-47.

Bayne B.L. (1969) The gregarious behaviour of the larvae of Ostrea edulis L. at settlement. Journal of the Marine Biological Association UK 49, 327-356.

Bayne B.L. (1976) The biology of mussel larvae. In: Marine Mussels: Their Ecology and Physiology (ed. by B.L. Bayne), pp. 81-120. Cambridge University Press, Cambridge, UK.

Bayne B.L. (1983) The physiological ecology of marine molluscan larvae. In:The Mollusca.Vol. III. Development (ed. by N.H. Verdonk, J.A.H. Van der Biggelaar \& A.S. Tompa), pp. 229-343. Academic Press, New York, USA.

Beaumont A.R. \& Budd M.D. (1982) Delayed growth of mussel (Mytilus edulis) and scallop (Pecten maximus) veliger at low temperatures. Marine Biology 71, 97-100.

Coeroli M.D., De Gaillande D.E., Landret J.P. \& Coatanea D. (1984) Recent innovations in cultivation of molluscs in French Polynesia. Aquaculture 39, 45-67.

Davis H.C. \& Calabrese A. (1964) Combined effects of temperature and salinity on development of eggs and growth of larvae of M. mercenaria and C. virginica. Fisheries Bulletin 63, 643-655.

Davis H.C. \& Calabrese A. (1969) Survival and growth of larvae of the European oyster (Ostrea edulis L.) at different temperatures. Biological Bulletin 136, 193-199.
Doroudi M.S., Southgate P.C. \& Mayer R.J. (1999) The combined effects of temperature and salinity on embryos and larval of the black-lip pearl oyster, Pinctada margaritifera (L.). Aquaculture Research 30 , 271-279.

Eyster L.S. \& Pechenik J.A. (1987) Attachment of Mytilus edulis larvae on algal and byssal filaments is enhanced by water agitation. Journal of Experimental Marine Biology Ecology 114, 99-110.

Falmagne C. (1983) Problems associated with the rearing and setting of larvae of the California mussel Mytilus californianus Conrad, in a hatchery. Journal of Shellfish Research 3, 112.

Falmagne C. (1984) The combined effect of temperature/salinity on survival and growth of Mytilus californianus larvae (a response surface analysis). Washington Sea Grant Publication, WSG-7H-84-6 (abstract).

Guillard R.L. (1983) Culture of phytoplankton for feeding marine invertebrates. In: Culture of Marine Invertebrates (ed. by C.J. Berg Jr), pp. 108-132. Hutchinson Ross Publishing Company, Stroudberg, PA, USA.

Hancock D.A. (1973) The relationship between stock and recruitment in exploited invertebrates. Journal du Counseil International pour L' Exploration Scientifique de la Mer 164, 113-131.

Henderson B.A. (1982) Practical methods of handling and remote setting eyed pediveliger larvae of the Pacific oyster, Crassostrea gigas (Thurnberg). Journal of Shellfish Research 2, 119-120.

Helm M.M. \& Millican P.F. (1982) Experiments in the hatchery rearing of Pacific oyster, Crassostrea gigas (Thurnberg). Aquaculture 11, 1-12.

His E., Robert R. \& Dinet A. (1989) Combined effects of temperature and salinity on fed and starved larva of the Mediterranean mussel Mytilus galloprovincialis and the Japanese oyster Crassostrea gigas. Marine Biology 100, $455-463$.

Hrs-Brenko M. (1973) Gonad development, spawning and rearing of Mytilus sp. larvae in the laboratory. Studies and Reviews G.F.C. M. 52, 53-65.

Hrs-Brenko M. (1978) The relationship of temperature and salinity to larval development in mussels (Mytilus galloprovincialis Lamarck). In: Physiology and Behaviour of Marine Organisms (ed. by D.S. McLusky \& A.J. Berry), pp. 359-365. Pergamon Press, UK.

Hrs-Brenko M. \& Calabrese A. (1969) The combined effect of salinity and temperature on larvae of the mussel Mytilus edulis. Marine Biology 4, 224-226.

Hurley D.H. \& Walker R.L. (1997) Effects of temperature and salinity upon larval growth, survival and development in hatchery reared southern Atlantic surf clams Spisula solidissima similis. Journal of the World Aquaculture Society $\mathbf{2 8}$, 407-411.

Krishnan A. (1987) Studies on larval nutrition in the pearl oyster Pinctada fucata (Gould), 263 pp. PhD Thesis, Cochin University, Cochin, India. 
Lemos M.B.N., Nascimento I.A., De Araujo M.M.S., Pereira S.A., Bahia I. \& Smith D.H. (1994) The combined effects of salinity, temperature, antibiotic and aeration on larval growth and survival of the mangrove oyster Crassostrea rhizophorae. Journal of Shellfish Research 13, 187-192.

Loosanoff V.L. (1954) New advances in study of bivalve larvae Venus mercenaria in relation to temperature. American Scientist 1, 59-81.

Loosanoff V.L. \& Davis H.C. (1963) Rearing of bivalve molluscs. Advances in Marine Biology 1,1-136.

Loosanoff V.L., Miller W.S. \& Smith P.B. (1951) Growth and setting of larvae of Venus mercenaria in relation to temperature. Journal of Marine. Research 1, 59-81.

Lough R.G. (1974) A re-evaluation of the combined effects of temperature and salinity and growth of Mytilus edulis larvae using response surface techniques. Proceedings of the National Shellfish Association 64, 73-76.

Lough R.G. (1975) A re-evaluation of the combined effects of temperature and salinity on survival and growth of bivalve larvae using response-surface techniques. Fisheries Bulletin. US 73, 86-94.

Lough R.G. \& Gonor J.J. (1973) A response-surface approach to the combined effects of temperature and salinity on the larval development of Adula californiensis (Pelecypoda: Mytilidae). 1. Survival and growth of three and fifteen day old larvae. Marine Biology 22, 241-250.

Lutz R.A. \& Kennish M.J. (1992) Ecology and morphology of larval and early post larval mussels. In: The Mussel Mytilus. Ecology, Physiology, Genetics and Culture (ed. by E. Gosling), pp. 53-85. Elsevier, Amsterdam, The Netherlands.

Pechenik J.A., Eyster L.S., Widdows J. \& Bayne B.L. (1990) The influence of food concentration and temperature on growth and differentiation of blue mussel larvae, Mytilus edulis L. Journal of Experimental Marine Biology and Ecology 136, 47-64.

Prytherch H.F. (1934) The role of copper in the setting, metamorphosis and distribution of the American Oyster, Ostrea virginica. Ecological Monograph 4, 47-107.

Rao V.K., Kumari L.K. \& Qasim S.Z. (1976) Aquaculture of green mussel Mytilus viridis L: Spawning, fertilization and larval development. Indian Journal of Marine Science 5, 113-116.

Robert R., His E. \& Dinet A. (1988) Combined effects of temperature and salinity on fed and starved larvae of the European flat oyster Ostrea edulis. Marine Biology 97, 95-100.

Satuito C.G., Natoyama K., Yamazaki M. \& Fusetani N. (1994) Larval development of the mussel Mytilus edulis galloprovincialis cultured under laboratory conditions. Fisheries Science 60, 58-65.

Siddall S.E. (1979a) Temporal changes in the salinity and temperature requirements of tropical mussel larvae. Proceedings of the World Mariculture Society 9, 549-566.
Siddall S.E. (1979b) Effects of temperature and salinity on metamorphosis in two tropical mussels. Proceedings of the National Shellfish Association 69, 199.

Sivalingam P.M. (1977) Aquaculture of green mussel, Mytilus viridis Linnaeus, in Malaysia. Aquaculture 11, 297-312.

Sprung M. (1984a) Physiological energetics of mussel larvae (Mytilus edulis). 1. Shell growth and biomass. Marine Ecology and Progressive Series 17, 283-293.

Sprung M. (1984b) Physiological energetics of mussel larvae (Mytilus edulis). II. Food uptake. Marine Ecology and Progressive Series 17, 295-303.

Sprung M. (1984c) Physiological energetics of mussel larvae (Mytilus edulis). III. Respiration. Marine Ecology and Progressive Series 18, 171-178.

Sprung M. (1984d) Physiological energetics of mussel larvae (Mytilus edulis). IV. Efficiencies. Marine Ecology and Progressive Series 18, 179-186.

Sreenivasan P.V., Rao S.K. \& Poovannan P. (1989) Survival of hatchery produced green mussel seed in different salinities. Marine Fish Information Service Technical \& Extension Series 95, 6-7.

Sreenivasan P.V., Rao S.K., Poovannan P. \& Thangavelu R. (1988a) Growth of larvae and spat of green mussel Perna viridis (Linnaeus) in hatchery. Marine Fish Information Service Technical \& Extension Series 79, 23-26.

Sreenivasan P.V., Rao S.K., Poovannan P. \& Thangavelu R. (1988b) Preliminary observations on the efficiency of some microalgal foods on the growth of green mussel larvae. Marine Fish Information Service Technical \& Extension Series 89, 29.

Stickney A.P. (1964) Salinity, temperature and food requirements of soft-shell calm larvae in laboratory culture. Ecology 45, 283-291.

Strathmann M.F. (ed.) (1987) Reproduction and Development of Marine Invertebrates of the Northern Pacific Coast, 670 pp. University of Washington Press, Seattle,WA, USA.

Tan S.H. (1997) Effect of salinity on hatching, larval growth, and survival in the green mussel Perna viridis. Phuket Marine Biological Centre Special Publication 17, 279-284.

Tan S.H. \& Wong T.M. (1996) Effect of holding temperature on setting performance of Crassostrea belcheri (Sowerby) larvae. Phuket Marine Biological Centre Special Publication 16, 47-52.

Tan W.H. (1975) Egg and larval development in green mussel M. viridis. Veliger 18, 151-155.

Trevelyan G.A. \& Chang E.A. (1983) Experiments of larval rearing of California mussel (Mytilus californianus). Journal of the World Mariculture Society 14, 137-148.

Widdows J. (1973) The effects of temperature on metabolism and activity of Mytilus edulis. Netherlands Journal of Sea. Research 7, 387-398.

Widdows J. (1991) Physiological ecology of mussel larvae. Aquaculture 94, 147-163. 